engaged in pursuing Red-winged Starlings over the marshes of the neighbourhood. When this Hawk is angry, it raises the feathers of the upper part of the head, so as to make them appear partially tufted. The cry at this time may be represented by the syllable kee, kee, kee, repeated eight or ten times in rapid succession, and much resembling that of the Pigeon-Hawk (Falco columbarius) or the European Kestril. The young of this species bear no resemblance to those of the Goshawk.

Cooper's Hawk, Falco Cooperii, Bonap. Amer. Orn. Young.

Falco CooperiI, Bonap. Syn., App., p. 433 . Young.

Stanley Hawk, Falco Stanleii, Aud. Orn. Biog., vol. ii. p. 245. Adult Male.

Stanley Hawk, Falco Stanleii, Aud. Orn. Biog., vol. i. p. 186. Young.

\title{
Adult Male.
}

Tail rounded, tarsi moderately stout. Adult male dull bluish-grey above; the tail with four broad bands of blackish-brown, and tipped with white; the upper part of the head greyish-black; lower parts transversely barred with light red and white, the throat white, longitudinally streaked. Female similar, with the bands on the breast broader. Young umber-brown above, more or less spotted with white, the tail with four blackish-brown bars; lower parts white, each feather with a longitudinal narrow, oblong, brown spot.

Male, 20, 36. Female, 22, 38.

\section{SHARP-SHINNED OR SLATE-COLOURED HAWK.}

$$
\text { A Astur fuscus, Gmel. }
$$

PLATE XXV.-Male and Female.

It is mentioned in the Fauna Boreali-Americana, that a specimen of this bird was killed in the vicinity of Moose Factory, and that it has been deposited by the Hudson's Bay Company in the Zoological Museum of London. This specimen I have not seen, but confiding entirely in the accuracy of every fact mentioned by the authors of that work, I here adduce it as a proof of the extraordinary range of this species in America, which from the extreme north extends to our most southern limits, perhaps far beyond them, during its autumnal and winter migrations. I have met with it in every State or Territory of the Union that I have visited. In the spring of 1837 , it was abundant in Texas, where it appeared to be travelling east- 


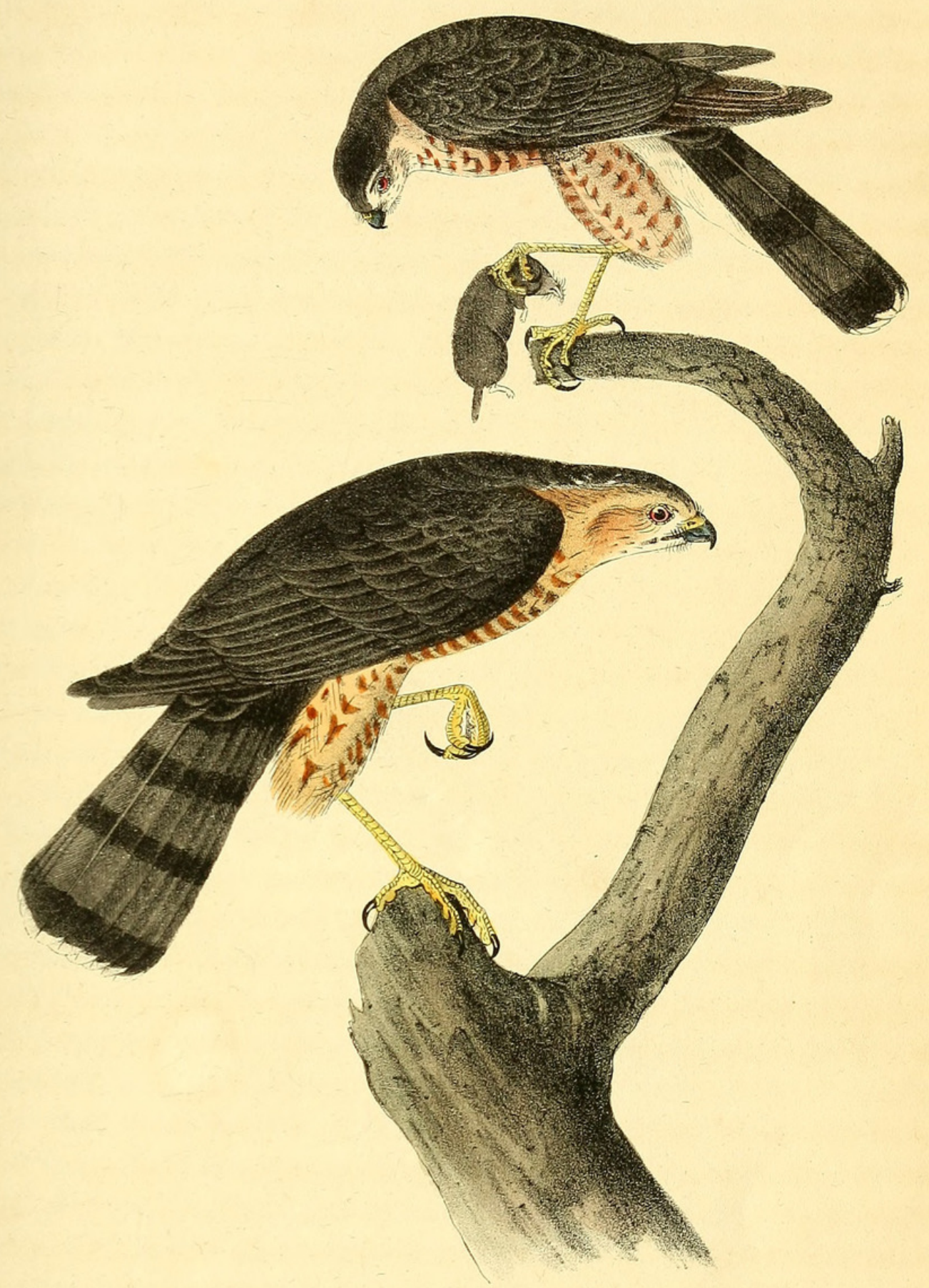

R. .

Shartps shimned Stlawe. 

ward. I have a specimen procured by Mr. Townsend in the neighbourhood of the Columbia River; and, when on my way towards Labrador, I met with it plentifully as far as the southern shores of the Gulf of St. Lawrence, beyond which, however, none were observed by me or any of my party.

I never saw this daring little marauder on wing without saying or thinking "There goes the miniature of the Goshawk!" Indeed, reader, the shortness of the wings of the Sharp-shinned Hawk, its long tail, although almost perfectly even, instead of being rounded as in the Goshawk, added to its irregular, swift, vigorous, varied, and yet often undecided manner of flight, greatly protracted however on occasion, have generally impressed upon me the idea alluded to. While in search of prey, the Sharp-shinned Hawk passes over the country, now at a moderate height, now close over the land, in so swift a manner that, although your eye has marked it, you feel surprised that the very next moment it has dashed off and is far away. In fact it is usually seen when least expected, and almost always but for a few moments, unless when it has procured some prey, and is engaged in feeding upon it. The kind of vacillation or wavering with which it moves through the air appears perfectly adapted to its wants, for it undoubtedly enables this little warrior to watch and to see at a single quick glance of its keen eyes every object, whether to the right or to the left, as it pursues its course. It advances by sudden dashes, as if impetuosity of movement was essential to its nature, and pounces upon or strikes such objects as best suit its appetite; but so very suddenly that it appears quite hopeless for any of them to try to escape. Many have been the times, reader, when watching: this vigilant, active, and industrious bird, I have seen it plunge headlong among the briary patches of one of our old fields, in defiance of all thorny obstacles, and, passing through, emerge on the other side, bearing off with exultation in its sharp claws a Sparrow or Finch, which it had surprised when at rest. At other times I have seen two or three of these Hawks, acting in concert, fly at a Golden-winged Woodpecker while alighted against the bark of a tree, where it thought itself secure, but was suddenly clutched by one of the Hawks throwing as it were its long legs forward with the quickness of thought, protruding its sharp talons, and thrusting them into the back of the devoted bird, while it was endeavouring to elude the harassing attacks of another, by hopping and twisting round the tree. Then down to the ground assailants and assailed would fall, the Woodpecker still offering great resistance, until a second Hawk would also seize upon it, and with claws deeply thrust into its vitals, put an end to its life; when both the marauders would at once commence their repast.

On several such occasions, I have felt much pleasure in rescuing different species of birds from the grasp of the little tyrant, as whenever it seizes one 
too heavy to be carried off, it drops to the ground with it, and, being close by, I have forced it to desist from committing further mischief, as it fears man quite as much as its poor quarry dreads itself. One of these occurrences, which happened in the neighbourhood of Charleston, in South Carolina, is thus related in my journal.

Whilst walking one delightful evening in autumn, along the fine hedgerow formed by the luxuriant Rocky Mountain rose-bushes, I observed a male of this species alighted in an upright position on the top bar of a fence opposite to me. I marked it with particular attention, to see what might follow. The Hawk saw me as plainly as I did him, and kept peeping now at me and now at some part of the hedge opposite, when suddenly, and with the swiftness of an arrow, it shot past me, entered the briars, and the next instant was moving off with a Brown Thrush, Turdus rufus, in its talons. The Thrush, though seized by the sharp claws of the marauder, seemed too heavy for him to carry far, and I saw both falling to the ground. On running up, I observed the anxiety of the Hawk as I approached, and twice saw it attempt to rise on wing to carry off its prize; but it was unable to do so, and before it could disengage itself I was able to secure both. The Thrush must have been killed almost instantaneously, for, on examining it, I found it quite dead.

My friend Thomas Nuttall, Esq., tells us that in the "thinly settled parts of the States of Georgia and Alabama, this Hawk seems to abound, and proves extremely destructive to young chickens, a single one having been known regularly to come every day until he had carried away between twenty and thirty. At noon-day, while I was conversing with a planter, one of these Hawks came down, and without ceremony, or heeding the loud cries of the housewife, who most reluctantly witnessed the robbery, snatched away a chicken before us." Again, while speaking of the wild and violent manner of this bird, he adds, "descending furiously and blindly upon its quarry, a young Hawk of this species, broke through the glass of the greenhouse at the Cambridge Botanic Garden; and fearlessly passing through a second glass partition, he was only brought up by the third, and caught, though little stunned by the effort. His wing-feathers were much torn by the glass, and his flight in this way so impeded as to allow of his being approached."

Whilst travelling to some distance, the Sharp-shinned Hawk flies high, though in a desultory manner, with irregular quick flappings of the wings, and at times, as if to pause for awhile and examine the objects below, moves in short and unequal circles, after which it is seen to descend rapidly, and then follow its course at the height of only a few feet from the ground, visiting as it were every clump of low bushes or briar patches likely to be 
supplied with the smaller birds, on which it principally feeds. Again, after having satisfied its hunger, this little warrior at times rises to a great height, and indeed now and then is scarcely discernible from the ground.

I found a nest of this Hawk in a hole of the well-known "Rock-in-cave" on the Ohio River, in the early part of the spring of 1819. It was simply constructed, having been formed of a few sticks and some grasses carelessly interwoven, and placed about two feet from the entrance of the hole. I had the good fortune to secure the female bird, while she was sitting on her eggs, which were nearly hatched, and it was from that individual that I made the figure in the plate. The eggs, four in number, were almost equally rounded at both ends, though somewhat elongated, and their ground colour was white, with a livid tinge, scarcely discernible however amid the numerous markings and blotches of reddish-chocolate with which they were irregularly covered. The second opportunity which I had of seeing a nest of this species, occurred not far from Louisville in Kentucky, when I accidentally observed one of these Hawks dive into the hollow prong of a broken branch of a sycamore overhanging the waters of the Ohio. Here the eggs were five in number, and deposited on the mouldering fragments of the decayed wood. The third and last opportunity happened when I was on my way from Henderson to St. Genevieve, on horseback. I saw a pair of these birds forming a nest in the forks of a low oak, in a grove in the centre of the prairie which I was then crossing. The young in the nest I have never seen.

This interesting species usually resorts to the fissures of rocks for the purpose of there passing the hours of repose, and generally in places by no means easy of access, such as precipitous declivities overhanging some turbulent stream. It is often not until the darkness has so much gained on the daylight as to render objects difficult to be distinguished, that it betakes itself to its place of rest, and then I have only been assured of its arrival by the few cries which it utters on such occasions. The earliness of its departure has often much puzzled me, for with all my anxiety to witness it, I have never succeeded in doing so, although on two or three occasions I have watched the spot more than half an hour before dawn, and remained patiently waiting until long after the sun had risen, when I clambered to the hole, and always found it empty.

The food of this Hawk consists chiefly of birds of various sizes, from the smallest of our warblers to the Passenger Pigeon or young chickens, the latter appearing to afford a special temptation to it, as has been above related. I am also aware that it feeds occasionally on small reptiles and insects, and I shot the male represented in the plate, on wing, whilst it held in its claws the small Shrew also represented. It is extremely expert at seizing some of 
our smaller snakes and lizards, and not unfrequently snatches up a frog while basking in the sun.

The difference of size observed between the males and females, as well as between inclividuals of the same sex, is very remarkable; and no doubt it was on account of this very great disparity that WILson described specimens of each sex as distinct species. Its notes are short, shrill, and repeated in a hurried manner, when the bird is wounded and brought to the ground. It often emits cries of this kind while falling, but suddenly becomes silent when it comes to the earth, and then makes off swiftly, with long and light leaps, keeping silent until approached. Although a small bird, it possesses considerable muscular power, and its extremely sharp claws are apt to inflict severe pain, should a person lay hold of it incautiously.

Slate-coloured Hawk, Falco Pennsylvanicus, Wils. Amer. Orn., vol. vi. p. 13. Adult Male.

Sharp-shinned Hawk, Falco velox, Wils. Amer. Orn., vol. vi. p. 116. Young Female.

Falco velox, Bonap. Syn., p. 29.

F ALco fuscus, Bonap. Syn., Append., p. 433.

Accipiter Pennsylvanicus, Slate-coloured Hawk, Swains. and Rich. F. Bor. Amer., vol. ii. p. 44.

American Brown or Slate-coloured Hawk, Nutt. Man., vol. ii. p. 87.

Sharp-Shinned or Slate-coloured Hawk, Falco fuscus, Aud. Amer. Orn., vol, iv. p. 522. Adult.

Tail even, tarsi extremely slender. Adult male bluish-grey above; the tail with four broad bands of blackish-brown, and tipped with white; upper part of head darker; lower parts transversely barred with light red and white, the throat white, longitudinally streaked. Female similar, more tinged with yellow beneath, and with the bands on the breast broader. Young umberbrown above, more or less spotted with white, the tail with four dark brown bars; lower parts white, each feather with a longitudinal narrow, oblong, brown spot. Miniature of Falco Cooperii, and intimately allied to Astur Nisus.

Male 11 $\frac{1}{4}, 20 \frac{1}{2}$. Female 14, 26. 


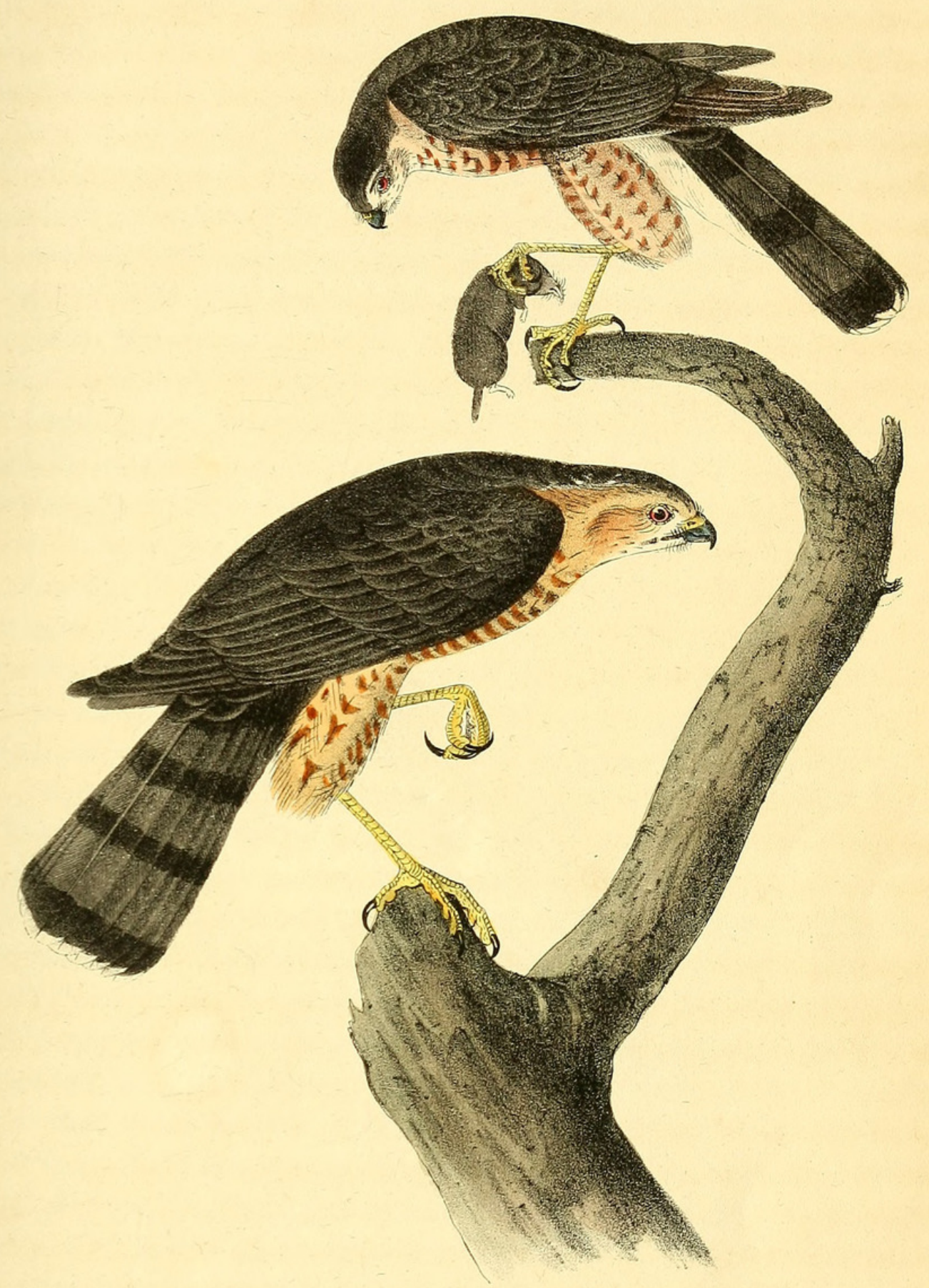

R. .

Shartps shimned Stlawe. 


\section{$2 \mathrm{BHL}$ Biodiversity Heritage Library}

Audubon, John James. 1840. "Sharp-Shinned or Slate-Coloured Hawk, Astur fuscus, Gmel. [PI. 25]." The birds of America : from drawings made in the United States and their territories 1, 100-104. https://doi.org/10.5962/p.319138.

View This Item Online: https://www.biodiversitylibrary.org/item/124833

DOI: https://doi.org/10.5962/p.319138

Permalink: https://www.biodiversitylibrary.org/partpdf/319138

\section{Holding Institution}

Smithsonian Libraries

\section{Sponsored by}

Biodiversity Heritage Library

\section{Copyright \& Reuse}

Copyright Status: NOT_IN_COPYRIGHT

This document was created from content at the Biodiversity Heritage Library, the world's largest open access digital library for biodiversity literature and archives. Visit BHL at https://www.biodiversitylibrary.org. 